\title{
ІСТОРИЧНІ АСПЕКТИ РОЗВИТКУ КРИМІНАЛЬНОї ВІДПОВІДАЛЬНОСТІ ЗА УМИСНЕ ПОШКОДЖЕННЯ АБО РУЙНУВАННЯ ТЕЛЕКОМУНІКАЦІЙНОӤ МЕРЕЖІ У XIX CT.
}

ЮРІКОВ Олександр Олександрович - викладач циклу загальних та кримінально-правових дисциплін Київського центру первинної професійної підготовки «Академія поліції» навчально-наукового інституту № 1 Національної академії внутрішніх справ

ORCID: https://orcid.org/0000-0002-6900-6887

DOI 10.32782/NP.2021.3.17

Проаналізовано генезу кримінальної відповідальності за умисне пошкодження або руйнування телекомунікаиійної мережі у ХІХ ст. Визначено, що предметом посягання на об'єкти телекомунікацій були технічні засоби і споруди телеграфу, зв'язку, радіомовлення, перші з яких виникли наприкінці XVIII cm., а широке застосування отримали лише в середині XIX cm. у зв'язку з появою електромагнітного телеграфуу.

Науково доведено, шзо на територї Украйни 27 квітня 1855 року вперше було встановлено відповідальність за посягання на телеграби у зв'язку з набуттям иинності Закону Російсъкої імперї № 29253 «Про покарання за пошкодження телеграфів».

1857 року було перевидано Звід законів Російсъкої імперій, $i$ зміст Закону № 29253 «Про покарання за пошкодження телеграбів» у первинному вигляді дублювався в cm. 1625-1635 підрозділу II «Про порушення Уставів телеграфічних» глави XI «Про порушення Уставів поштових $i$ телеграбічних» розділу VIII «Про злочини $і$ проступки проти громадського благоустрою $i$ благочиння» тому XV Уложення про покарання кримінальні та виправні Зводу законів Російсъкоі isnepii.

1864 року в Російсъкій імперї було проведено судову ребборму, у зв'язку з чим прийнято Статут про покарання, що накладаються мировими суддями. Глава 8 «Про порушення Уставів поштового і телеграбного» иього Статуту містила норми, які передбачали кримінальну відповідальність за посягання на телеграфне обладнання.

У редакиї 1885 року Уложення про покарання кримінальні та виправні відповідальність за посягання на об'єкти телеграбу було передбачено в ст. 1139-1148 niдрозділу II «Про порушення Устава телеграбного» глави ХI «Про порушення Уставів поштового та телеграфбого» розділу VIII «Про злочини i проступки проти громадсъкого благоустрою і благочиння».

Констатовано, що попри перевидання Уложення про покарання кримінальні та виправні, дію Статуту про покарання, щьо накладаються мировими суддями, не припинено, що призводило до певних колізій під иас притягнення винних до кримінальної відповідальності за посягання на об'єкти телекомунікаиій (зв'язку).

Ключові слова: телекомунікациї, телеграбб, зв'язок, обладнання, технічні засоби, споруди електрозв'язку, об'єкти телекомунікачій, посягання, пошкодження, руйнування.

Постановка проблеми

Усебічне та повне дослідження кримінальної відповідальності за умисне пошкодження або руйнування телекомунікаційної мережі неможливе без вивчення історичних аспектів виникнення та розвитку норми кримінального закону, яка передбачає відповідальність за це діяння. Такий аналіз дає змогу проаналізувати генезис кримінальної відповідальності за посягання на об'єкти телекомунікацій, передумови виникнення 
сучасної кримінально-правової норми, яка передбачає відповідальність за умисне пошкодження або руйнування телекомунікаційної мережі (ст. 360 КК України), а також визначити соціальну обумовленість існування цієї норми в чинному кримінальному законодавстві України, іiї недоліки та можливості вдосконалення.

\section{Аналіз останніх досліджень і публікацій}

Кримінальну відповідальність за умисне пошкодження або руйнування телекомунікаційної мережі, а також деякі їі аспекти досліджували у своїх працях такі вітчизняні й зарубіжні вчені: І. Б. Газдайка-Василишин, О. П. Дячкін, Р. О. Мовчан, С. В. Незнайко, О. Г. Сандул, О. В. Таран та ін.

Тому метою статті $\epsilon$ висвітлення історичних аспектів розвитку кримінальної відповідальності за умисне пошкодження або руйнування телекомунікаційної мережі у XIX ст.

\section{Виклад основного матеріалу}

У науці кримінального права України дослідження генезису правових явищ здійснюють переважно 3 моменту прийняття першого законодавчого акта, який регулював кримінально-правові відносини, однак не завжди таке рішення є обгрунтованим i доцільним. 3 огляду на те, що предметом посягання на об'єкти телекомунікацій є технічні засоби і споруди телеграфу, зв'язку, радіо-, телемовлення, телекомунікацій, перші $з$ яких виникли наприкінці XVIII ст., а широке застосування отримали лише в середині XIX ст. у зв'язку з появою електромагнітного телеграфу, досліджувати генезис кримінальної відповідальності за умисне пошкодження або руйнування телекомунікаційної мережі доцільно не з часу виникнення першої пам'ятки кримінального права чи законодавства України, а саме з моменту законодавчого закріплення норми, яка встановлюе кримінальну відповідальність за такі діяння.

3 XIX ст. переважна більшість земель сучасної України належала до складу Російської імперії. 27 квітня 1855 року було ви- дано Закон Російської імперії № 29253 «Про покарання за пошкодження телеграфів», яким уперше на території України було встановлено відповідальність за посягання на телеграфи. Він містив дві частини. Перша частина охоплювала 12 пунктів, які визначали протиправні діяння та покарання за їх вчинення. Друга частина встановлювала порядок ознайомлення населення держави iз цими правилами. Спочатку цей закон належав до тому II «Звід губернських установ» Зводу Законів 1842 року, а не до тому XV « Уоження про покарання кримінальні та виправні» [1, с. 295-298]. Тобто спершу законодавець не передбачив кримінальної відповідальності за посягання на телеграф.

1857 року було перевидано Звід законів Російської імперії, і зміст Закону № 29253 «Про покарання за пошкодження телеграфів» у первинному вигляді дублювався в ст. 1625-1635 підрозділу II «Про порушення Уставів телеграфічних» глави ХІ «Про порушення Уставів поштових і телеграфічних» розділу VIII «Про злочини і проступки проти громадського благоустрою і благочиння» тому XV Уложення про покарання кримінальні та виправні Зводу законів Російської імперії [2, с. 417-421].

Стаття 1625 (п. 1, 2 Закону № 29253) передбачала кримінальну відповідальність за умисне або вчинене 3 необережності пошкодження обладнання телеграфу, будь-які інші дії, що спричинили припинення телеграфного з'єднання. Такі діяння каралися штрафом, арештом або тілесними ушкодженнями [2, с. 417]. Якщо таке діяння вчинено 3 необережності й винний повідомив про це працівників телеграфу та відвернув серйозні наслідки, то покарання було найменш тяжким. Тобто законодавець того часу вже розумів, що суспільна небезпека цього злочину полягає в припиненні зв'язку, а тому визначив такі наслідки обов'язковими. Крім того, із самого початку існування кримінальної відповідальності за посягання на об'єкти телеграфу було очевидно, що до зазначених вище наслідків може призвести не лише пошкодження телеграфу, а й інші дії.

Стаття 1626 (п. 3 Закону № 29253) передбачала кримінальну відповідальність за пошкодження телеграфу через необереж- 


\section{Кримінальне право, кримінальний процес та криміналістика}

ність, якщо це спричинило тілесні ушкодження різного виду та ступеня тяжкості чи смерть потерпілого. Таке діяння каралося позбавленням волі на строк від 3 до 6 місяців. Натомість умисне пошкодження обладнання телеграфу каралося різного виду покараннями: від позбавлення всіх прав до заслання в різні регіони Російської імперії та тілесних ушкоджень (ст. 1627 (п. 4 Закону № 29253)) [2, с. 418]. Отже, умисне пошкодження телеграфу було суспільно небезпечним і кримінально караним незалежно від наслідків такого діяння, а вчинення його 3 необережності - тільки в разі настання наслідків у вигляді тілесних ушкоджень або смерті потерпілого. Не цілком зрозумілим 3 боку законодавця є виокремлення ст. 1627 та призначення більш тяжкого покарання, ніж у ст. 1625. Ці статті були схожими, різнилися лише наслідками - припинення телеграфного з'єднання, які в ст. 1625 передбачені були як обов'язкові, а ст. 1627 була формальним складом. Пошкодження телеграфу, що спричинило тілесні ушкодження або смерть потерпілого, каралося також різного виду покараннями: від позбавлення всіх прав до заслання в різні регіони Російської імперії та тілесних ушкоджень (ст. 1629 (п. 6 Закону № 29253)). Порівняно зі ст. 1627, такі покарання були більш тяжкими через їх розмір (майже вдвічі вище) [2, с. 419-420].

У підрозділі II «Про порушення Уставів телеграфічних» глави XI «Про порушення Уставів поштових і телеграфічних» розділу VIII «Про злочини і проступки проти громадського благоустрою і благочиння» були не тільки заборонні норми, а й роз'яснювальні - ст. 1628 (п. 5 Закону № 29253). У ній зазначено, що пошкодження телеграфу, вчинене з метою викрадення його складових, каралося незалежно від вартості викраденого на підставі правил про сукупність злочинів, передбачених ст. 165 тому XV Уложення про покарання кримінальні та виправні Зводу Законів Російської імперії, за найтяжчим покаранням, передбаченим ст. 1627 [2, с. 419].

Стаття 1630 (п. 7 Закону № 29253) передбачала кримінальну відповідальність за припинення чи уповільнення телеграфного з'єднання, зміну телеграфних знаків шля- хом насильницьких дій щодо працівників телеграфної установи. На підставі ст. 296298 тому XV Уложення про покарання кримінальні та виправні Зводу законів Російської імперії, а також залежно від виду насильницьких дій винного такі діяння каралися позбавленням усіх прав, каторжними роботами, тілесними ушкодженнями тощо. У ст. 1631 (п. 8 Закону № 29253) передбачено кримінальну відповідальність за пошкодження телеграфу з метою зупинення передачі урядового припису чи доносу, які відомі винному, що каралося одним із покарань, передбачених у ст. 1630, залежно від важливості інформації та інших обставин. Для вибору покарання не мало значення, чи було застосовано насильство до працівників телеграфу під час посягання [2, с. 420].

За умисне пошкодження телеграфного з'єднання з метою вчинити або сприяти вчиненню злочинів проти держави, передбачених ст. 257, 278, 282 та 287 тому XV Уложення про покарання кримінальні та виправні Зводу законів Російської імперії було передбачено покарання у вигляді позбавлення всіх прав і смертної кари (ст. 1632 (п. 9 Закону № 29253)). Умисне пошкодження телеграфічних з'єднань вчинено з метою вчинення іншого злочину проти фізичних осіб або власності, сприянню вчиненню такого злочину, каралося на підставі правил про сукупність злочинів, передбачених ст. 165 тому XV Уложення про покарання кримінальні та виправні Зводу законів Російської імперії, за найтяжчим покаранням (ст. 1633 (п. 10 Закону № 29253)) [2, c. $420-421]$.

У ст. 1634 (п. 11 Закону № 29253)) визначено порядок відшкодування збитків, завданих злочинами, передбаченими ст. 1625-1633 тому XV Уложення про покарання кримінальні та виправні Зводу законів Російської імперії. Слід акцентувати на тому, що в разі вчинення цих злочинів службовими особами телеграфних управлінь, підрядниками чи працівниками цих підрядників, які прийняли на утримання телеграфне обладнання, то покарання призначали за відповідними статтями підрозділу II «Про порушення Устава телеграфного» глави XI «Про порушення Уставів поштово- 
го та телеграфного» розділу VIII «Про злочини і проступки проти громадського благоустрою і благочиння», однак воно повинно було бути найтяжчим (ст. 1635 (п. 11 Закону № 29253)) [2, с. 421].

1864 року в Російській імперії було проведено судову реформу, у зв'язку з чим прийнято Статут про покарання, що накладаються мировими суддями, який містив 13 глав, з яких 12 були нормами Особливої частини. Глава 8 «Про порушення Уставів поштового і телеграфного» містила норми, які передбачали кримінальну відповідальність за посягання на телеграфне обладнання [3; 4, с. 96-97]. Переважна більшість цих норм стосується порушення правил роботи 3 телеграфним обладнанням, проте не 3 його пошкодженням тощо. Аише ст. 101 передбачала кримінальну відповідальність за пошкодження обладнання телеграфів та телефонів через необережність, що могло спричинити припинення телеграфного або телефонного з'єднання. Такі діяння карали штрафом, а у випадку припинення зв'язку - арештом на строк до 1 місяця або штрафом [3]. Тобто зазначена стаття частково дублювала положення ст. 1625 тому XV Уложення про покарання кримінальні та виправні Зводу законів Російської імперії 1857 року, водночас поширювала кримінально-правову охорону на об'єкти телефонного зв'язку. Доречно зазначає В. В. Бабаніна, що цей нормативно-правовий акт хоч і вирізнявся високим рівнем законотворчості, чітко визначав ознаки складів конкретних діянь, однак спричинив складнощі в правозастосуванні внаслідок одночасної дії з Уложенням про покарання кримінальні та виправні. Це спонукало до суттєвої зміни зазначеного Уложення [4, с. 97].

1885 року Звід законів Російської імперії було перевидано, а також змінено том XV Уложення про покарання кримінальні та виправні. У цій редакції кримінального закону відповідальність за посягання на об'єкти телеграфу було передбачено в ст. 1139-1148 підрозділу II «Про порушення Устава телеграфного» глави XI «Про порушення Уставів поштового та телеграфного» розділу VIII «Про злочини i проступки проти громадського благо- устрою і благочиння» [5]. Стаття 1139 встановлювала кримінальну відповідальність за пошкодження телеграфу через необережність, що спричинило тілесні ушкодження різного виду й ступеня тяжкості або смерті потерпілого. Таке діяння каралося позбавленням волі від 2 до 4 місяців. Водночас ст. 1140 передбачала кримінальну відповідальність за умисне пошкодження телеграфу, яке каралося позбавленням будь-яких прав і роботами у виправних арештних відділеннях на строк від 1,5 до 3 років. Ця стаття мала примітку, у якій зазначено, що за цією статтею карається також пошкодження телефонних ліній зв'язку. Таким чином, перші кримінально-правові норми, які встановлювали відповідальність за посягання на об'єкти телекомунікацій, були диференційовані залежно від форми вини. Крім того, слід акцентувати на тому, що пошкодження телеграфу через необережність було суспільно небезпечним і кримінально караним лише у випадку спричинення тілесних ушкоджень або смерті, а умисне таке діяння не передбачало настання цих наслідків. Однак ч. 1 ст. 1142 передбачала кримінальну відповідальність за умисне пошкодження телеграфу, що спричинило смерть потерпілого, що каралося позбавленням будь-яких прав і роботами у виправних арештних відділеннях на строк від 3,5 до 4 років, а ч. 2 - те саме діяння, що спричинило тілесні ушкодження будьякого виду та ступеня тяжкості, каралося позбавленням будь-яких прав і роботами у виправних арештних відділеннях на строк від 2,5 до 3,5 років. Тобто умисне посягання на об'єкти телеграфу, що спричинило тілесні ушкодження або смерть потерпілого, було передбачено окремою статтею та каралося значно суворіше, ніж таке діяння, що не спричинило відповідні наслідки [5].

Цікавою з позицій юридичної техніки є стаття 1141, яка передбачала кримінальну відповідальність за пошкодження телеграфу з метою викрадення його складових. Санкція цієї статті не передбачала покарання, водночас у ній зазначено, що за таке діяння покарання призначали на підставі встановлених ст. 152 Уложення про покарання кримінальні та виправні 1885 року 


\section{Кримінальне право, кримінальний процес та криміналістика}

правил про сукупність злочинів. Можливо, ця норма є роз'яснювальною, однак, з огляду на будову диспозиції, можна стверджувати, що вона є заборонною та відсилочною до ст. 1140 для визначення покарання за умисне пошкодження телеграфу та ст. 152 для правильного призначення покарання. Крім того, у цій статті викладено правило кваліфікації посягання на об'єкти телеграфу (телекомунікацій) - тобто таке діяння у випадку заволодіння складовими телеграфу підлягало додатковій кваліфікації за статтями, які передбачали кримінальну відповідальність за посягання на власність (залежно від форми посягання - крадіжка, грабіж, розбій тощо). Схожою є норма ст. 1146, у якій зазначено, що у випадку умисного пошкодження телеграфних з'єднань вчинено з метою вчинення іншого злочину проти фізичних осіб або власності, чи сприяння вчиненню такого злочину, то дії винного слід карати на підставі правил про сукупність злочинів [5].

Стаття 1143 передбачала кримінальну відповідальність за припинення або уповільнення передання інформації шляхом насильницьких дій щодо працівників телеграфної установи. У цій статті відповідальність диференційовано залежно від виду й ступеня небезпеки насильницьких дій винного. Такі дії карали позбавленням усіх прав і каторжними роботами на строк від 12 до 20 років. У ст. 1144 передбачено кримінальну відповідальність за пошкодження телеграфу з метою зупинити передання урядового припису чи доносу, які відомі винному. Такі дії карали одним із покарань, передбачених у ст. 1143, залежно від важливості інформації. Для вибору міри покарання не мало значення, чи було застосовано насильство до працівників телеграфу під час посягання. Статтю 1145 в останній редакції Уложення про покарання кримінальні та виправні 1885 року виключено [5].

Те, що попередні норми є саме заборонними, а не роз'яснювальними, підтверджує ст. 1147, яка передбачала порядок відшкодування збитків, завданих злочинами, передбаченими ст. 1139-1146 Уложення про покарання кримінальні та виправні 1885 року. Вчинення цих злочинів службо- вими особами телеграфних управлінь, підрядниками чи працівниками цих підрядників, які прийняли на утримання телеграфне обладнання, карали найтяжчою мірою покарання (ст. 1148) [5].

\section{Висновки}

Кримінальна відповідальність за посягання на об'єкти телекомунікацій була доволі диференційованою і передбачена різними статтями. Однак з огляду на покарання та зміст диспозиції деяких статей не цілком зрозуміло, чому вони не були об'єднані в одну статтю.

Предметами посягань були засоби та споруди зв'язку, зокрема телеграфу. Формою прояву об'єктивної сторони визнано лише пошкодження, натомість знищення чи руйнування не було передбачено в зазначених вище статтях. Такі діяння цілком охоплено поняттям «пошкодження», а тому окремої конкретизації не потребувало. Суб'єкт посягань на об'єкти телекомунікацій був загальним. Суб'єктивна сторона характеризувалася виною у формі умислу та необережності.

Загалом криміналізація посягань на об'єкти телекомунікацій була і залишається позитивним аспектом кримінально-правової охорони власності, громадської безпеки й обороноздатності держави.

\section{入iтература}

1. Полное собрание законов Российской империи. Собрание (1825-1881) : в 55 т. Т. 30 (1855) : Ч. 1 : Законы (28881-30012).

2. Свод законов Российской империи : в 15 т. Т. 15 : Законы уголовные (Уложение о наказаниях уголовных и исправительных). СПб. : Тип. 2-го Отделения Собственной Е.И.В. канцелярии, 1857. 602 с.

3. Уставъ о наказаніяхъ, налагаемыхъ мировыми судьями, 1864 г.

4. Бабаніна В. В. Кримінальне законодавство України: механізм створення та реалізації : дис. ... д-ра юрид. наук : 12.00.08. Київ, 2021. 600 с.

5. Свод законов Российской империи : в 16 т. Т. 15 : Положение о наказаниях (Уложение о наказаниях уголовных и исправительных). 


\section{References}

1. Polnoe sobranye zakonov Rossyiskoi ymperyy. Sobranye (1825-1881) : v 55 t. T. 30 (1855) : Ch. 1 : Zakony (28881-30012) [Complete collection of laws of the Russian Empire. Collection (1825-1881) : in 55 volumes T. 30 : Part 1 : Laws (28881-30012)] [in Russia].

2. Svod zakonov Rossyiskoi ymperyy : v 15 t. T. 15 : Zakony uholovnye (Ulozhenye o nakazanyiakh uholovnykh y yspravytelnykh) (1857) [Code of laws of the Russian Empire : in 15 volumes. T. 15 : Criminal laws (Code of penalties and correctional)]. SPb. : Typ. 2-ho Otdelenyia Sobstvennoi E.Y.V. kantseliaryy[in Russia].

3. Ustav o nakazaniiakh, nalahaemykh myrovymy sudiamy (1864) [Charter on Punishments Imposed by Justices of the Peace] [in Russia].

4. Babanina V. V. (2021). Kryminalne zakonodavstvo Ukrainy: mekhanizm stvorennia ta realizatsii [Criminal legislation of Ukraine: mechanism of creation and realization]. Kyiv [in Ukraine].

5. Svod zakonov Rossyiskoi ymperyy : v 16 t. T. 15 : Polozhenye o nakazanyiakh (Ulozhenye o nakazanyiakh uholovnykh y yspravytelnykh) [Code of laws of the Russian Empire : in 16 volumes. Vol. 15 : Provisions on punishments (Code on penal and correctional punishments)] [in Russia].

\section{Yurikov Oleksandr HISTORICAL ASPECTS OF THE DEVELOPMENT OF CRIMINAL LIABILITY FOR INTENTIONAL DAMAGE OR DESTRUCTION OF THE TELECOMMUNICATIONS NETWORK IN THE XIX GENTURY}

The genesis of criminal liability for intentional damage or destruction of the telecommunications network in the XIX century is analyzed. It is determined that the subject of encroachment on telecommunications facilities were technical means and facilities of the telegraph, communications, broadcast, the first of which appeared in the late XVIII century., And were widely used only in the middle of the XIX century due to the advent of the electromagnetic telegraph.

It has been scientifically proven that on April 27, 1855, liability for encroachment on telegraphs was established for the first time in Ukraine in connection with the entry into force of the Law of the Russian Empire № 29253 «On Punishment for Damage to Telegraphs».

In 1857, the Code of Laws of the Russian Empire was republished, and the content of Law № 29253 «On Punishment for Damage to Telegraphs» was duplicated in its original form in Art. 1625-1635 of Subsection II «On Violation of Telegraphic Statutes» of Chapter XI «On Violation of Postal and Telegraphic Statutes» of Section VIII «On Crimes and Misdemeanors Against Public Welfare and Devotion» vol.

In 1864, the Russian Empire underwent a judicial reform, which resulted in the adoption of the Statute of Punishments Imposed by Justices of the Peace. Chapter 8 «On Violation of the Statutes of the Post and Telegraph» of this Statute contained provisions that provided for criminal liability for encroachment on telegraph equipment.

In the wording of the 1885 Code of Punishment, criminal and corrective liability for encroachment on telegraph objects was provided in Art. 1139-1148 of subsection II «On Violation of the Telegraph Charter» of Chapter XI «On Violation of the Postal and Telegraph Statutes» of Section VIII «On Crimes and Misdemeanors against Public Improvement and Denomination».

It was stated that despite the re-issuance of the Criminal and Correctional Penal Code, the Statute of Penalties imposed by justices of the peace has not been terminated, which has led to certain conflicts in bringing the perpetrators to justice for encroaching on telecommunications.

Keywords: telecommunications, telegraph, communication, equipment, technical means, telecommunication facilities, telecommunications facilities, encroachment, damage, destruction. 